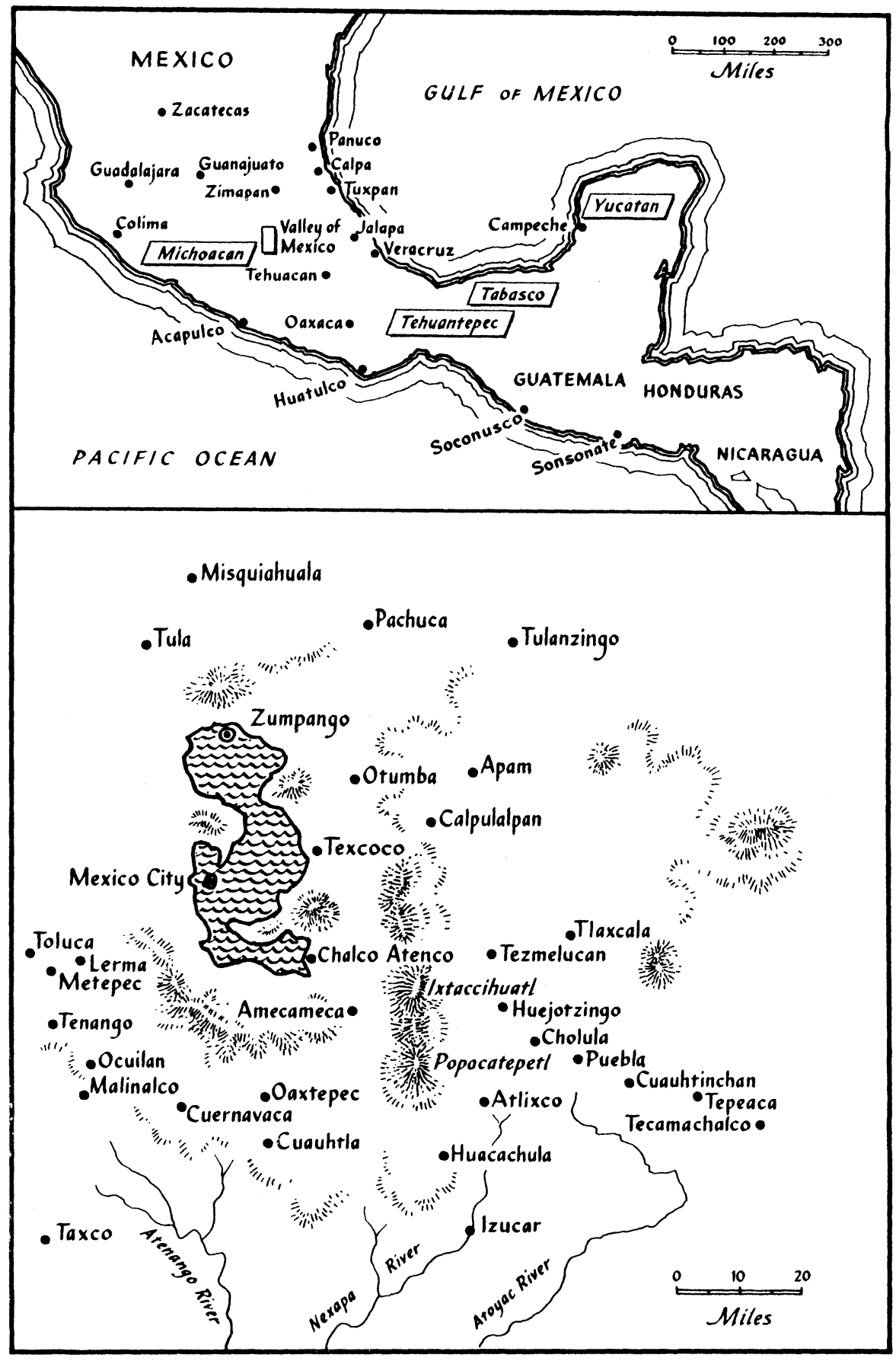




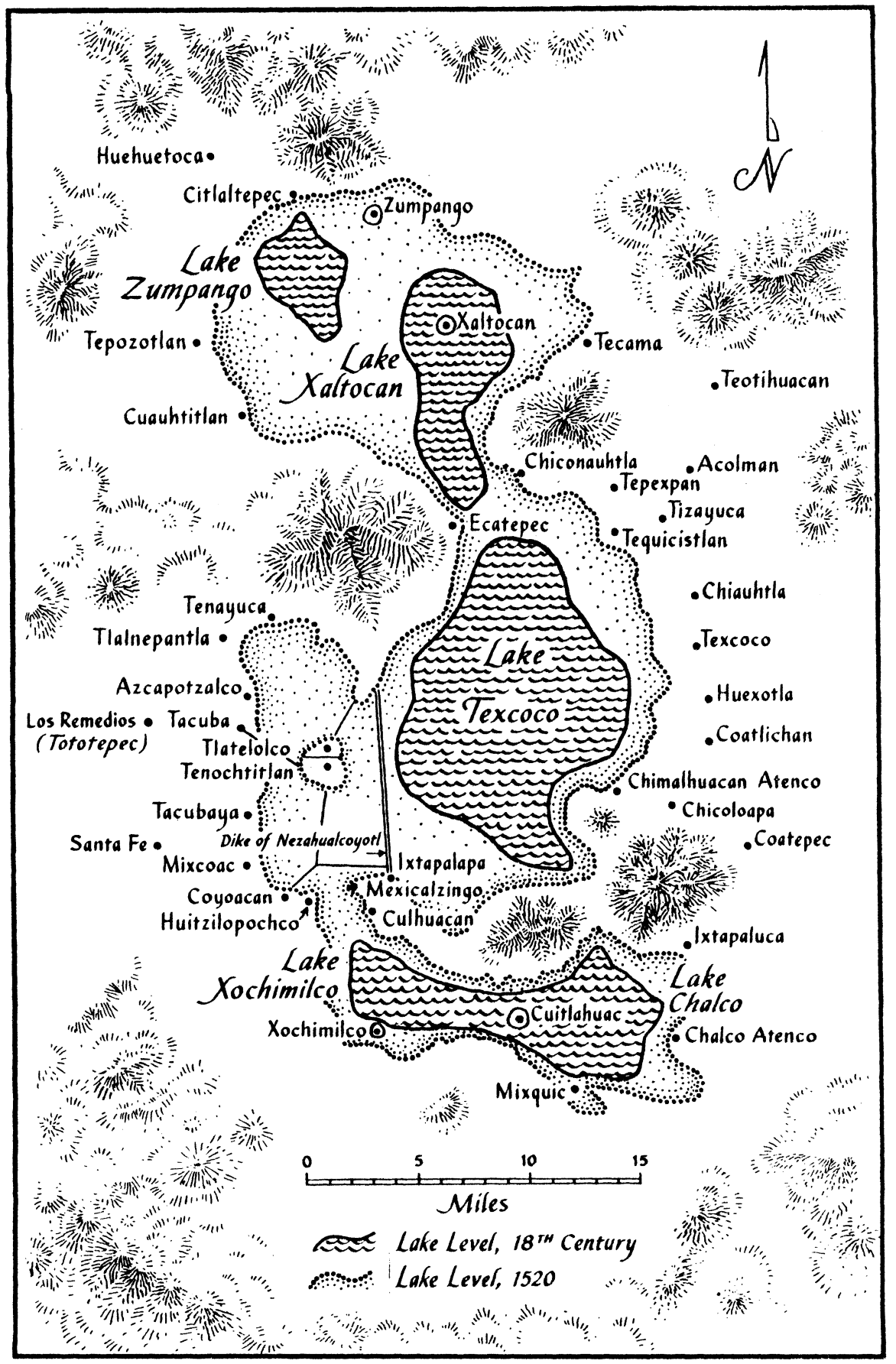




\section{The Aztecs Under Spanish Rule}


